\title{
Characterization of Physicochemical and Hydraulic Properties of Organic and Mineral Soilless Culture Substrates and Mixtures
}

\author{
Mohammad R. Gohardoust ${ }^{1}$, Asher Bar-Tal ${ }^{2}$, Mohaddese Effati ${ }^{1}$ and Markus Tuller ${ }^{1, *}$ \\ 1 Department of Environmental Science, The University of Arizona, Tucson, AZ 85721, USA; \\ gohardoust@email.arizona.edu (M.R.G.); effati@email.arizona.edu (M.E.) \\ 2 Institute of Soil, Water and Environmental Sciences, The Volcani Center, Agricultural Research \\ Organization (ARO), Bet Dagan 50250, Israel; abartal@volcani.agri.gov.il \\ * Correspondence: mtuller@email.arizona.edu; Tel.: +1-520-621-7225
}

Received: 20 August 2020; Accepted: 12 September 2020; Published: 16 September 2020

\begin{abstract}
Many arid and semiarid regions of the world face serious water shortages that are projected to have significant adverse impacts on irrigated agriculture and create unprecedented challenges for providing food and water security for the rapidly growing human population in a changing global climate. Consequently, there is a momentous incentive to shift to more resource-efficient soilless greenhouse production systems. Though there is considerable empirical and theoretical research devoted to specific issues related to control and management of soilless culture systems, a comprehensive approach that quantitatively considers relevant physicochemical processes within containerized soilless growth modules is missing. An important first step towards development of advanced soilless culture management strategies is a comprehensive characterization of hydraulic and physicochemical substrate properties. In this study we applied state-of-the-art measurement techniques to characterize six soilless substrates and substrate mixtures [i.e., coconut coir, perlite, volcanic tuff, perlite/coconut coir (50/50 vol.- $\%)$, tuff/coconut coir (70/30 vol.- $\%)$, and Growstone ${ }^{\circledR} /$ coconut coir (50/50 vol.- $\left.\left.\%\right)\right]$ that are used in commercial production in Israel and the United States. The measured substrate properties include water retention characteristics, saturated hydraulic conductivity, packing and particle densities, as well as phosphorus and ammonium adsorption isotherms. In addition, integral water availability and integral energy parameters were calculated to compare investigated substrates and provide valuable information for irrigation and fertigation management.
\end{abstract}

Keywords: soilless culture; organic and mineral substrates and mixtures; laboratory characterization; hydraulic properties; physicochemical properties

\section{Introduction}

The projected growth of the world population to around 9.7 billion by 2050 [1] poses unprecedented challenges for providing and sustaining food and water security and mitigating associated economic inequalities and social tensions that threaten global security [2,3]. This is further exacerbated by climate change via alterations of precipitation patterns, more likely occurrence of climate extremes (e.g., prolonged droughts), and modification of diurnal and seasonal temperature regimes [4] and soil degradation that leads to an alarming reduction of arable land. Because of these imminent challenges as well as a strong demand for high-quality, out-of-season vegetables, fruits, and ornamentals in many industrial countries and the ban of methyl bromide fumigation of horticultural field soils, there is an increasing incentive to shift from soil to more resource-efficient soilless culture [5]. 
Substrates used in soilless culture systems exhibit major advantages over soils. Besides the alleviated risk for spreading soil-borne pathogens, physicochemical properties of growth substrates can be controlled within narrow margins, which commonly leads to healthier plants and higher yields when compared to soil-based production [6,7].

Organic substrates that are extensively used in soilless culture include peat moss, compost, coconut coir, bark and other wood-based materials, and biochar, all of which are commonly mixed with inorganic substrates such as perlite, volcanic tuff, expanded clay granules, pumice, zeolite, and sand, in order to improve their physicochemical properties [8,9].

Though the same physical principles apply to both soilless substrates and soils, their physical and hydraulic properties are vastly different, which is of significant importance for management and control of soilless growth systems. In addition, there are fundamental differences with regard to dynamic water, air, and nutrient distribution processes, and root growth and development between spatially confined containerized production systems and unconfined field soils. While water flow and nutrient transport in growth containers is restricted by an impermeable container bottom with drainage holes, water drains and redistributes to much deeper layers in agricultural soils unless natural impediments exist. This leads to vastly different infiltration and redistribution dynamics requiring more intensive management of soilless systems. The smaller the root zone the more intensive the production system needs to be managed to provide a stress-free rhizosphere environment for optimum plant growth [5].

While soils are well-researched, and many discovered soil physical principles are readily available for application to soilless substrates, their adaptation and translation to substrates appear to lag behind. The physical properties of essence for the design and management of containerized soilless production systems include bulk density $(B D)$, particle density (i.e., specific gravity), the water characteristic $(W C)$, and hydraulic conductivity $(K)[10,11]$. The substrate $W C[12]$ that relates the water content to the matric potential (i.e., capillary and adsorptive surface forces that hold water under subatmospheric pressure within the substrate matrix) and $K$ are the most important physical properties that govern water flow and distribution processes [13] and aeration [14] in containerized soilless systems. The matric potential (h) [15] determines the "ease" for plant roots to extract water from the substrate and is commonly expressed as a negative (subatmospheric) pressure. In general, all irrigation practices that explicitly attempt to avoid water stress in soilless production are confined to a matric potential range from 0 to $-8 \mathrm{kPa}$. In some substrates, such as rockwool, the range is even narrower, with the onset of water stress occurring if $h$ is allowed to attain values $<-5 \mathrm{kPa}$. In contrast, matric potentials encountered in field soils may well go as low as $-75 \mathrm{kPa}$; in such systems matric potentials rarely rise above $-10 \mathrm{kPa}$, except during or immediately after irrigation [16].

Several concepts related to the $W C$ and $K$ have been introduced to determine plant water availability. These include plant available water capacity [17], easily available water and water buffering capacity [18], container capacity [19-21], limiting and least limiting water range [22,23], and the integral water capacity [24], the later accounting for aeration and root penetration. The more recently introduced integral energy concept calculates the energy required to extract water from the growth medium $[14,25]$. The water flux in soilless substrates that may significantly vary due to large changes of hydraulic conductivity within a narrow $h$ range is another important parameter for irrigation management to avoid plant water stress $[26,27]$. Accurate measurements of hydraulic substrate properties (i.e., $W C$ and $K)$ are also essential for the parameterization of numerical computer codes for the simulation of water and nutrient dynamics in containerized soilless systems. Such simulations aid with the optimization of substrate mixtures for specific plants as well as with the design and management of soilless systems (i.e., container geometry and irrigation amount and frequency), which may reduce costly and time consuming trial and error greenhouse experiments [14].

Nutrient supply in conjunction with irrigation (i.e., fertigation) is another important aspect of soilless culture management that requires insights about the adsorption of nutrients on substrate surfaces. For example, phosphorus and nitrogen need to be continuously supplied due to limited container volumes and associated restricted nutrient buffering capacities [28-30]. Rapid depletion of 
phosphorus after fertigation is a well-documented phenomenon caused by electrostatic adsorption onto substrate surfaces and slow formation of new solid metal-phosphorus compounds [31,32]. To increase phosphorus uptake by plant roots, high frequency fertigation is commonly applied to induce nonequilibrium conditions [33-35]. Ammonium promotes optimum plant development and growth when the $\mathrm{NH}_{4}-\mathrm{N} /$ total-N ratio does not exceed plant specific thresholds that depend on species, rooting medium, root zone temperature, and $\mathrm{pH}$ [36-41]. For proper nutrient management, adsorption isotherms need to be determined to not only assure optimal growth conditions, but also to minimize nutrient loss in open-loop soilless culture systems.

The presented collaborative project that involves research teams from the U.S. and Israel was motivated by the rapidly growing demand for soilless growth media due to an ongoing momentous shift to more resource-efficient containerized soilless greenhouse production systems. It should be noted that the choice of soilless substrates and the selection of measured substrate properties was guided by ongoing production-scale greenhouse trials and the goal to utilize the obtained properties to parameterize a three-dimensional numerical code for simulation of water and nutrient dynamics in containerized growth modules to aid with their design and management. In the following we first discuss the selected substrates, then present a solid procedure for preparation of substrate mixtures, which is followed by an introduction of the applied state-of-the-art characterization techniques for the $W C$, saturated hydraulic conductivity $\left(K_{\text {sat }}\right)$, and particle density as well as for the measurement of phosphorus and ammonium adsorption isotherms. We conclude the paper with a thorough discussion of obtained results.

\section{Materials and Methods}

\subsection{Investigated Soilless Substrates}

Six soilless substrates and substrate mixtures, including perlite (Figure 1a), volcanic tuff (Figure 1b), coconut coir (Figure 1c), a 50/50 vol.-\% perlite/coconut coir mixture (Figure 1d), a 70/30 vol.- $\%$ volcanic tuff/coconut coir mixture (Figure 1e), and a 50/50 vol.- $\%$ foamed glass aggregate (i.e., Growstone $\left.{ }^{\circledR}\right) /$ coconut coir mixture (Figure 1f), were investigated.

Horticultural perlite (Figure 1a) is a naturally occurring amorphous volcanic glass with high water holding capacity, typically formed through hydration of obsidian [42,43]. Perlite is usually sieved and then heated to $1000^{\circ} \mathrm{C}$. At high temperature water evaporates, and when rehydrated perlite expands to 4 to 20 times of its original volume [9], which yields a lightweight substrate with high porosity. Perlite aggregates are chemically inert and pathogen free [44], two desired attributes when plants remain in the same substrate for prolonged time periods [9,45]. However, if perlite is applied in high amounts, a negative impact on plant growth due to nutrient leaching may occur [46,47].

Tuff is a common name for pyroclastic volcanic material, exhibiting high porosity and surface area (Figure 1b). The physicochemical properties of tuff are mainly dependent on mineral composition and the weathering stage $[48,49]$. In addition, grinding and sieving processes may alter these properties. Tuff commonly exhibits a $B D$ between 0.8 and $1.5 \mathrm{~g} \mathrm{~cm}^{-3}$ and a total porosity between 60 and $80 \%$. Tuff possesses a high buffering capacity and may adsorb or release nutrients, especially phosphorus, throughout the plant growth period [49,50].

Coconut coir (Figure 1c) is the mesocarp of Cocos nucifera L., containing short and medium length fibers left from industrial applications. Depending on origin and industrial source, there is a difference in physical and chemical characteristics [51,52]. The coconut coir dust is commonly sieved to desired sizes and washed to leach excess salts. Coconut coir exhibits remarkable physical and chemical properties such as high water holding capacity, good drainage and aeration properties, and high cation exchange capacity. It is also commonly used as a surrogate for peat and mixed with mineral substrates [53-55].

Foamed glass aggregates (Growstone ${ }^{\circledR}$, Growstone, LLC, Santa Fe, NM, USA) are made of recycled glass bottles and windows. The production process starts with crushing and grinding glass into a fine 
powder of vitreous soda lime glass, which is mixed with calcium carbonate ( $2 \%$ on weight basis) that acts as a foaming agent. When the mixture is heated it expands, thereby creating a network of fine pores $[9,56]$. After the cooling process, the solid block of foamed glass is crushed, tumbled, and sieved to various aggregate sizes. The aggregates are commonly mixed with organic substrates.
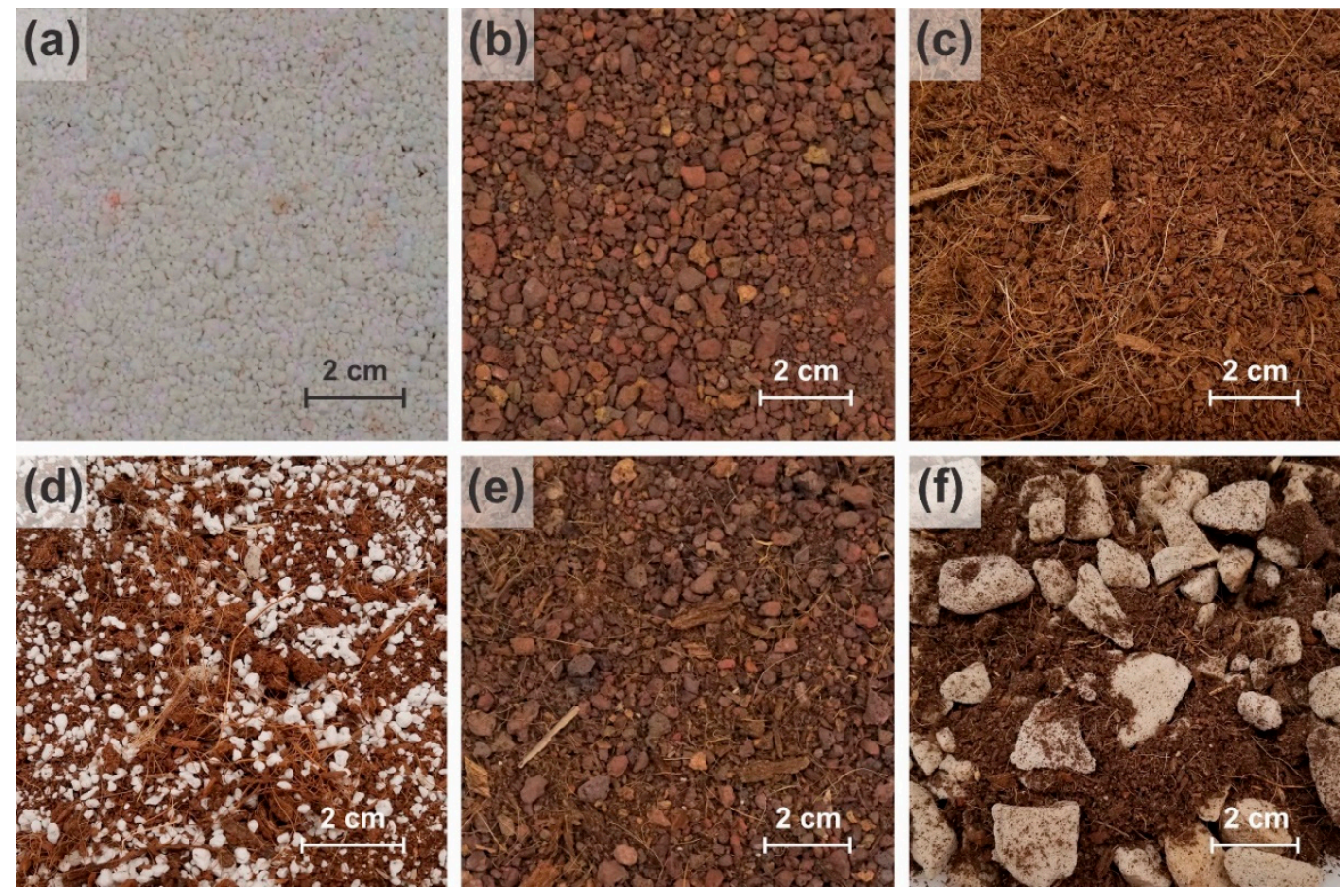

Figure 1. Investigated soilless substrates and substrate mixtures. (a) perlite, (b) tuff, (c) coconut coir, (d) 50/50 vol.-\% perlite/coconut coir mixture, (e) 70/30 vol.-\% volcanic tuff/coconut coir mixture, and (f) 50/50 vol.- $\%$ foamed glass aggregate/coconut coir mixture.

\subsection{Sample Preparation}

To obtain uniform and reproducible substrate samples for hydraulic characterization we first performed comprehensive compaction trials to determine the lowest and highest achievable dry bulk densities for the considered soilless substrates. The average dry bulk densities were then used as initial target bulk densities for preparation of samples for substrate $W C$ and $K_{\text {sat }}$ measurements. Because of particle segregation during transport, the $50 / 50$ vol.- $\%$ Growstone ${ }^{\circledR} /$ coconut coir mixture (Figure $1 \mathrm{f}$ ) supplied by Growstone, LLC was separated, remixed, and homogenized. All tests were performed in sextuplicate for each substrate and substrate mixture. We used air-dry samples as this is the most realistic scenario for large-scale greenhouse applications and also to avoid potential problems with hydrophobicity of coconut coir that may be induced during oven drying.

Subsamples of perlite, tuff, and coconut coir were first oven-dried to determine the air-dry gravimetric water content. Then, the thoroughly homogenized air-dried substrates were compacted into cylinders with known volume $\left(V_{C}\right)$ in multiple layers to achieve a uniform packing density. To achieve the lowest potential packing density, the substrates were poured into and carefully manually distributed within the cylinders without imposing a significant compaction force. Only on the very top the substrate particles were gently pushed inside the cylinder to obtain a smooth surface. To achieve the highest potential packing density, the substrates were compacted layer by layer with a rubber stopper mounted on a push rod. At the end, the lowest and highest dry bulk densities were determined, and the average values were used as the target density for sample preparation for $W C$ and $K_{\text {sat }}$ measurements.

Compaction trials were also performed for the 50/50 vol.- $\%$ perlite/coconut coir mixture, the $70 / 30$ vol.- $\%$ tuff/coconut coir mixture, and the $50 / 50$ vol.- $\%$ Growstone ${ }^{\circledR} /$ coconut coir mixture. 
First, several subsamples of the individual substrates to be mixed were collected and oven-dried to determine their air-dried gravimetric water content. Once the gravimetric water content of the individual mixture components was known, the substrates were poured into two separate cylinders of known volumes and compacted in the same fashion as described above for the lowest packing density. The air-dried mass of the substrates occupying a specific volume was then measured and the oven-dried masses per volume were calculated. The dry mass ratio $(\vartheta)$ may then be defined as:

$$
\vartheta=\frac{M_{O D v 1}}{M_{O D v 2}} \times R_{V}
$$

with $M_{O D v}$ as the oven-dried mass of substrates 1 or 2 occupying a specific volume and $R_{V}$ the volumetric substrate mixing ratio (i.e., 50/50 vol.-\% for perlite/coconut coir; 70/30 vol.-\% for tuff/coconut coir; and 50/50 vol.-\% for Growstone ${ }^{\circledR} /$ coconut coir).

For the compaction trials the air-dried substrate components were then mixed at the desired volumetric substrate mixing ratio and the resulting mixture was meticulously homogenized. The homogenized air-dried mixture was then compacted into cylinders in the same fashion as the individual substrates to obtain the lowest and highest achievable potential packing densities. After compaction, the mass of the air-dried mixture occupying the cylinder, $M_{A D m i x}$, was determined and the oven-dried masses of the individual components composing the sample were calculated as:

$$
\begin{gathered}
M_{O D 1}=\left[M_{A D m i x}-\frac{M_{A D m i x}}{\vartheta\left(\frac{1+\theta_{m 1}}{1+\theta_{m 2}}\right)+1}\right] \cdot \frac{1}{1+\theta_{m 1}} \\
M_{O D 2}=\frac{M_{A D m i x}}{\vartheta\left(\frac{1+\theta_{m 1}}{1+\theta_{m 2}}\right)+1} \cdot \frac{1}{1+\theta_{m 2}}
\end{gathered}
$$

where $M_{O D 1}$ and $M_{O D 2}$ are the oven-dry masses of substrate 1 and 2 , respectively, and $\theta_{m}$ is the gravimetric water content. The dry bulk density of the mixture $\left(\rho_{b-\text { mix }}\right)$, which is used as target value for further measurements, was derived as:

$$
\rho_{b-m i x}=\frac{M_{O D 1}+M_{O D 2}}{V_{C}}
$$

with $V_{C}$ as the cylinder volume. The mass of air-dry substrate required to fill a distinct volume $(V)$ at target bulk density was calculated as:

$$
M_{A D m i x}=\left[\frac{1+\theta_{m 1}}{1+\vartheta^{-1}}+\frac{1+\theta_{m 2}}{1+\vartheta}\right] \cdot \rho_{b-m i x} \cdot V_{C}
$$

\subsection{Substrate Water Characteristic and Integral Energy and Water Storage}

Tempe cells (Soilmoisture Equipment Corp., Santa Barbara, CA, USA) were used to measure the substrate WC curve. The Tempe cells were connected to a pressure manifold (Figure 2) with a high-resolution pressure/vacuum regulator and initially saturated samples were sequentially desaturated by applying increasing pressures. Each pressure step was maintained until the sample was in equilibrium with the applied pressure and the outflow ceased. A detailed description of the pressure desaturation method is provided in [12]. All measurements were performed in quintuplicate and averaged values are reported. 


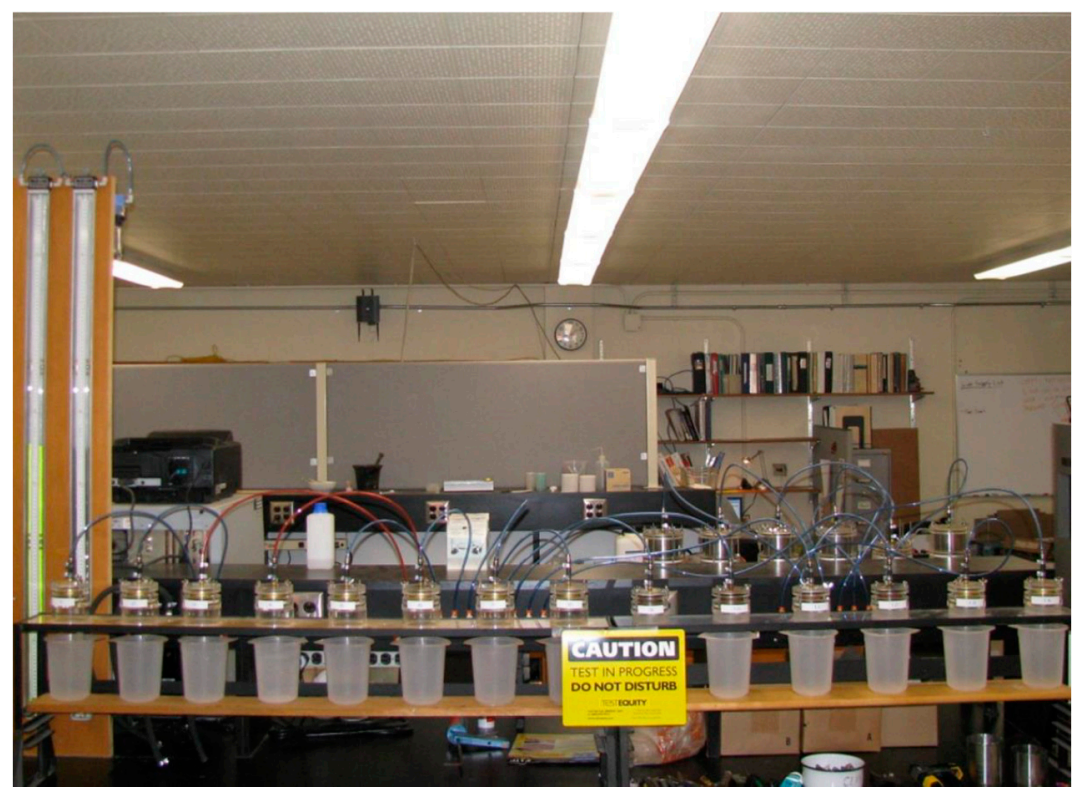

Figure 2. Setup of the Tempe cell experiment.

The van Genuchten model [57] (Equation (6)) was fitted to WC measurements for substrates exhibiting unimodal behavior and the Durner model [58] (Equation (7)) was fitted to WC measurements exhibiting bimodal behavior.

$$
\begin{gathered}
\theta(h)=\theta_{r}+\left(\theta_{s}-\theta_{r}\right)\left[\frac{1}{1+|\alpha h|^{n}}\right]^{m} \\
\theta(h)=\theta_{r}+\left(\theta_{s}-\theta_{r}\right)\left[(1-w)\left(\frac{1}{1+\left|\alpha_{1} h\right|^{n_{1}}}\right)^{m_{1}}+w\left(\frac{1}{1+\left|\alpha_{2} h\right|^{n_{2}}}\right)^{m_{2}}\right]
\end{gathered}
$$

where $\theta$ is the volumetric water content, $\theta_{r}$ and $\theta_{s}$ are the residual and saturated water contents respectively, $h$ is the matric potential, and $\alpha, n$, and $m$ are shape parameters with $m=1-1 / n$. $w$ is a weighting factor that varies between 0 and 1 and the indices 1 and 2 refer to the first and second substrate in the mixture, respectively.

To capture effects of the WC curve shape on plant water availability, rather than relying on two matric potential thresholds such as proposed in $[17,22,23]$, we calculated the integral water $\left(W_{I}\right)$ and energy $\left(E_{I}\right)$ storage following $[24,25]$ as:

$$
W_{I}\left[h_{i}, h_{f}\right]=\frac{1}{\left|h_{i}-h_{f}\right|} \int_{h_{f}}^{h_{i}} \theta(h) d h
$$

where the indices $i$ and $f$ are the wet and dry matric potential cut-offs, respectively. $W_{I}$ has units of volumetric water content and represents the weighted average of water contents between $h_{i}$ and $h_{f}$. The integral energy (i.e., the energy required to extract water from $\theta_{i}$ to $\theta_{f}$ ) was calculated as:

$$
E_{I}\left[\theta_{i}, \theta_{f}\right]=\frac{1}{\theta_{i}-\theta_{f}} \int_{\theta_{f}}^{\theta_{i}} h(h \theta) d \theta
$$

The integrals in Equations (8) and (9) were numerically solved with the MATLAB ${ }^{\circledR}$ —Version R2019a software package (MathWorks, Natick, MA, USA). Based on obtained WC parameters and 
selection of plant specific cut-off values for the wet- and dry-end matric potentials and water contents, substrate water availability can be determined as:

$$
R=\frac{W_{I}}{E_{I}}
$$

$R$ indicates the amount of water that can be extracted via exertion of a unit amount of energy by plant roots within the range of the wet- and dry-end thresholds. The higher $R$, the easier it is for plants to extract water.

\subsection{Saturated Hydraulic Conductivity}

For the $K_{\text {sat }}$ measurements we designed and fabricated an automated constant head device that was placed on a load cell attached to a laboratory jack and connected to a flow cell filled with substrate (Figure 3). The load cell was connected to a datalogger to record and monitor the weight change of the constant head container (i.e., Marriot tank) while water was flowing through the sample. In addition, the water temperature was continuously measured with a thermocouple and used to convert mass to volume change. The setup was initially thoroughly tested and adjusted to minimize flow resistance in the tubing and connectors. Each substrate was compacted into a flow cell at average bulk density (see Section 2.2). Before slowly saturating samples with water from the Marriot tank, they were flushed with $\mathrm{CO}_{2}$ for about $10 \mathrm{~min}$ at very low flow rate to enhance the saturation process. After sample saturation the constant head was adjusted with the lab jack and the experiment initiated. The experiment was terminated after several hours of steady state flow. Each substrate was measured in duplicate at 20,15,10, and $5 \mathrm{~cm}$ hydraulic heads. Darcy's law was applied to calculate $K_{\text {sat }}$ from the measured water flux density and set hydraulic heads [59].
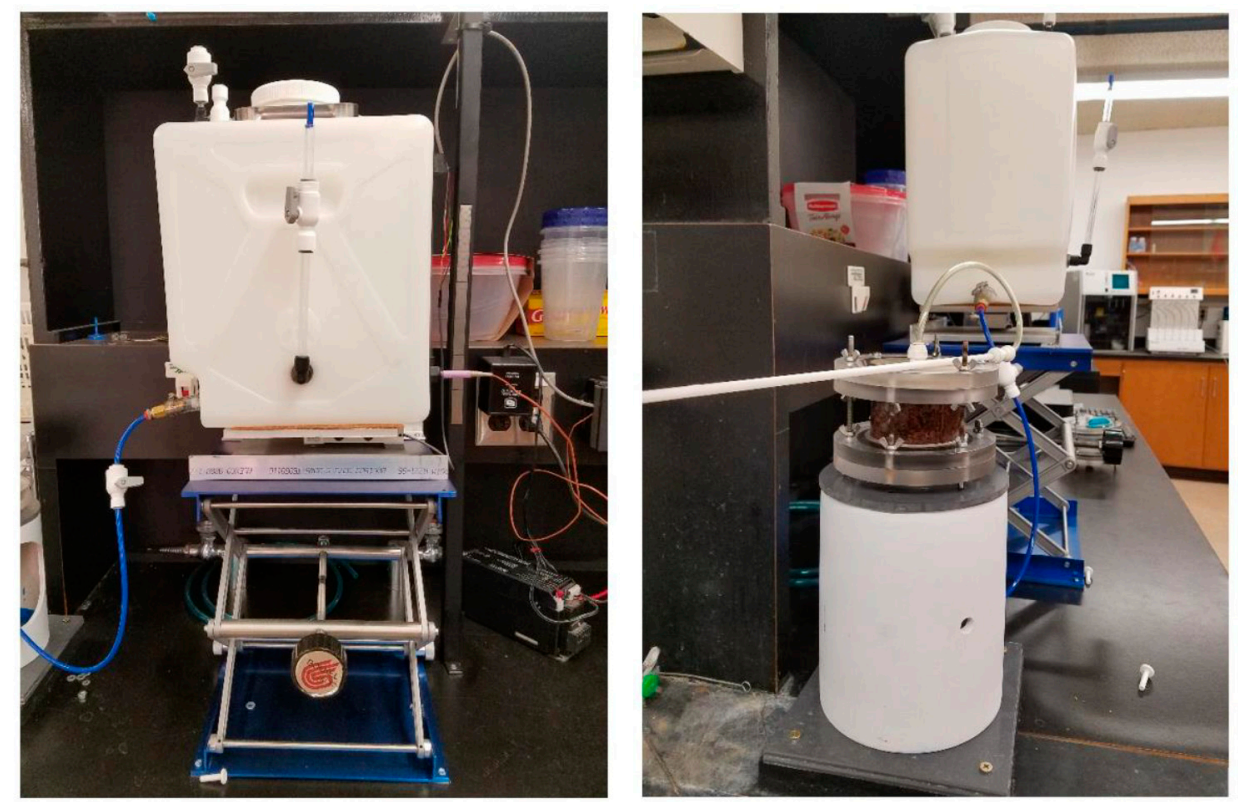

Figure 3. Automated constant head setup for $K_{\text {sat }}$ measurements.

\subsection{Particle Density}

While a standard water pycnometer [60] was used to measure the particle densities of tuff and coconut coir, nitrogen gas pycnometry was applied for the lighter perlite and Growstone ${ }^{\circledR}$ substrates. A Multipycnometer (Quantachrome Corp., Boynton Beach, FL, USA) with nitrogen as probing gas was used for the latter measurements. Gas pycnometry is based on Archimedes' fluid displacement principle and Boyle's gas expansion law. The volume of a solid or powder sample is determined via measuring the pressure drop that occurs when a known amount of pressurized gas initially contained 
in a reference cell with known volume $\left(V_{R}\right)$ is allowed to expand into a cell of known volume $\left(V_{C}\right)$ that contains the sample. The sample volume vs. is calculated as:

$$
V_{S}=V_{C}-V_{R}\left[\frac{P_{1}}{P_{2}}-1\right]
$$

where $P_{1}$ and $P_{2}$ are the pressures before and after gas expansion into the sample cell. All measurements were performed in quintuplicate. From the known oven-dry mass of the sample and its determined volume $V_{S}$, the particle density can be calculated. The particle densities of the mixtures were calculated based on their mixing ratios.

\subsection{Phosphorus Adsorption Isotherms}

Phosphorus adsorption isotherms were measured in triplicate with adsorption batch experiments. The substrates were air dried and a 1-g subsample was added to a $50 \mathrm{~mL}$ equilibration tube. Then $20 \mathrm{~mL}$ of $\mathrm{KH}_{2} \mathrm{PO}_{4}$ solution with concentrations of $0,1,5,10,50$, and $100 \mathrm{mg} \mathrm{KH} \mathrm{PO}_{4}-\mathrm{P}^{-1}$ in the background of $0.01 \mathrm{M} \mathrm{CaCl}_{2}$ was added to the tubes to obtain a soil/solution ratio of 1:20. The $\mathrm{pH}$ of the solution was adjusted with $1 \mathrm{M}$ sodium hydroxide to fall between 6.5 and 7.0. The samples were left to equilibrate for $24 \mathrm{~h}$ in an end-over-end shaker. The supernatant was extracted after centrifuging for $15 \mathrm{~min}$ at $12,000 \mathrm{rpm}$ and filtering with $0.2 \mu \mathrm{m}$ paper filters.

The analysis of the filtrate soluble reactive phosphorus was carried out with the ascorbic acid colorimetric method for perlite, tuff, and tuff-coir substrates. Required reagents were prepared as follows: Molybdate Reagent: $12.0 \mathrm{~g}$ of ammonium molybdate was dissolved in $250 \mathrm{~mL}$ of deionized water and $0.1455 \mathrm{~g}$ of antimony potassium tartrate was also dissolved in $500 \mathrm{~mL}$ of $5 \mathrm{~N} \mathrm{H}_{2} \mathrm{SO}_{4}$. Then $125 \mathrm{~mL}$ of ammonium molybdate solution was thoroughly mixed with the $500 \mathrm{~mL} \mathrm{H}_{2} \mathrm{SO}_{4}$-antimony potassium tartrate solution and diluted to one liter with deionized water using a volumetric flask. Color developing reagent was prepared as follows: in a $1 \mathrm{~L}$ volumetric flask, $0.739 \mathrm{~g}$ of ascorbic acid was dissolved in deionized water and $70 \mathrm{~mL}$ of the molybdate reagent added and brought to volume. A series of standard $\mathrm{PO}_{4}-\mathrm{P}$ solutions with concentrations of $0,1,2,3$, and $4 \mathrm{ppm}$, were prepared for calibration of the spectrophotometer each time a measurement was made. $1 \mathrm{~mL}$ of sample solution was mixed with $9 \mathrm{~mL}$ of color developing reagent in a small tube and its $\mathrm{P}$ concentration was measured after about $1 \mathrm{~h}$ with a spectrophotometer at $880 \mathrm{~nm}$ wavelength.

Because colorimetric determination of the phosphorus concentration requires a clear solution, which was not the case for samples containing considerable amounts of coconut coir (i.e., coconut coir, perlite/coconut core mixture, and Growstone ${ }^{\circledR} /$ coconut coir mixture), the total phosphorus concentrations for these substrates were measured with Inductively Coupled Plasma Mass Spectrometry (ICP-MS) at the Arizona Laboratory for Emerging Contaminants (ALEC).

The linearized Langmuir adsorption equation was fitted to the measured data to obtain the substrate sorption parameters:

$$
\frac{C}{S}=\frac{1}{k S_{\max }}+\frac{C}{S_{\max }}
$$

where $S$ is the total amount of $P$ retained $\left(\mathrm{mg} \mathrm{kg}^{-1}\right), C$ is concentration of $\mathrm{P}$ after 24 h equilibration $\left(\mathrm{mg} \mathrm{l}^{-1}\right), S_{\text {max }}$ is the maximum P sorption capacity $\left(\mathrm{mg} \mathrm{kg}^{-1}\right)$, and $k$ is a constant related to the bonding energy, $1(\mathrm{mg} \mathrm{P})^{-1}$. Additional details are provided in [61].

\subsection{Ammonium Adsorption Isotherms}

Ammonium adsorption isotherms were calorimetrically determined in triplicate in batch experiments. Ammonium solutions were prepared in concentrations of 0, 1, 5, 10, 50, and $100 \mathrm{mg}$

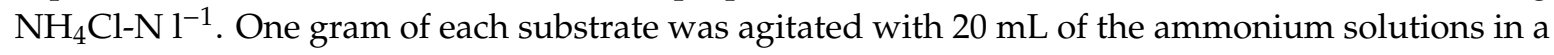
centrifuge tube for $3 \mathrm{~h}$ after adjusting the $\mathrm{pH}$ with $1 \mathrm{M}$ sodium hydroxide to fall between 6.5 and 7.0. Samples were then centrifuged and filtered with $0.2 \mu \mathrm{m}$ filter paper. The concentration of ammonium was measured with the salicylate method following [62] with the following reagents: 
1. Sodium salicylate-sodium nitroprusside solution (reagent 1): $33.0 \mathrm{~g}$ of $\mathrm{NaC}_{7} \mathrm{H}_{5} \mathrm{O}_{3}$ and $20.0 \mathrm{mg}$ of $\mathrm{Na}_{2} \mathrm{Fe}(\mathrm{CN})_{5} \mathrm{NO}_{5} \mathrm{H}_{2} \mathrm{O}$ was dissolved in deionized water and diluted to $100 \mathrm{~mL}$.

2. Buffer solution (reagent 2): $9.33 \mathrm{~g}$ of sodium citrate dihydrate and $4.0 \mathrm{~g}$ of $\mathrm{NaOH}$ were dissolved in deionized water and diluted to $100 \mathrm{~mL}$.

3. Hypochlorite solution (reagent 3 ): $5 \mathrm{~mL}$ of hypochlorite (10\% active chlorine) was dissolved in $25 \mathrm{~mL}$ deionized water.

Four $\mathrm{mL}$ of extracted ammonium solution was mixed in a glass tube with $0.9 \mathrm{~mL}$ combined reagent (i.e., one part of reagent 1 mixed with two parts of reagent 2 ). Then within one minute $0.1 \mathrm{~mL}$ of reagent 3 was added to the tube, which was then placed in a dark room for $120 \mathrm{~min}$ to allow the establishment of the emerald blue color. The absorbance of the chromophore was measured with a spectrophotometer at $647 \mathrm{~nm}$ wavelength and the Langmuir adsorption model (Equation (12)) was fitted to the measured data.

\section{Results and Discussion}

\subsection{Bulk and Particle Densities}

The lowest and highest dry bulk densities achieved with the packing procedures described in Section 2.2 are listed in Table 1. The average values were used as the target bulk densities for the samples used for the $W C$ and $K_{\text {sat }}$ measurements. Perlite was the lightest of the investigated substrates with an average bulk density of $0.076 \mathrm{~g} \mathrm{~cm}^{-3}$, followed by the perlite/coconut coir mixture. Tuff exhibited the highest bulk density with an average value of $1.15 \mathrm{~g} \mathrm{~cm}^{-3}$. From transportation and handling point of view low bulk densities are desirable [63]. The determined dry mass ratios for the substrate mixtures are also displayed in Table 1.

Table 1. Dry bulk densities and oven-dried mass ratios of mixtures determined with compaction experiments.

\begin{tabular}{cccccc}
\hline Substrates & $\begin{array}{c}\text { Mixing Ratio } \\
\text { (vol.-\%) }\end{array}$ & Dry Mass Ratio $(\vartheta)$ & \multicolumn{2}{c}{ Dry Bulk Density $\left(\mathrm{g} \mathrm{cm}^{-3}\right)$} \\
\cline { 4 - 6 } & & & Lowest & Highest & Average \\
\hline Perlite & - & - & 0.072 & 0.080 & 0.076 \\
Tuff & - & - & 1.100 & 1.200 & 1.150 \\
Coconut coir & $50 / 50$ & 0.73 & 0.100 & 0.120 & 0.110 \\
Perlite/coir & $70 / 30$ & 25.82 & 0.082 & 0.094 & 0.088 \\
Tuff/coir & $50 / 50$ & 2.89 & 0.875 & 0.975 & 0.925 \\
Growstone ${ }^{\circledR} /$ coir & & 0.180 & 0.190 & 0.185 \\
\hline
\end{tabular}

The average particle densities and associated standard errors (SE) are listed in Table 2. As discussed in Section 2.5, a standard water pycnometer was employed for tuff and coconut coir and a gas pycnometer was used for the perlite and Growstone ${ }^{\circledR}$ substrates. Perlite exhibits the lowest particle density. The obtained value of $0.739 \mathrm{~g} \mathrm{~cm}^{-3}$ falls within the reported range of $0.28-0.98 \mathrm{~g} \mathrm{~cm}^{-3}[64,65]$ - the variations are attributable to differences in the production process. The highest particle density of $2.653 \mathrm{~g} \mathrm{~cm}^{-3}$ was determined for tuff, which is due to the presence of significant amounts of metal oxides such as aluminum, iron, and magnesium [48].

Table 2. Measured particle densities.

\begin{tabular}{ccc}
\hline Substrates & Particle Density $\left(\mathrm{g} \mathrm{cm}^{-\mathbf{3}}\right)$ & Standard Error \\
\hline Perlite & 0.739 & 0.004 \\
Tuff & 2.653 & 0.015 \\
Coconut coir $_{\text {Growstone }}{ }^{\circledR}$ & 1.717 & 0.069 \\
Gr $^{\circ}$ & 1.621 & 0.014 \\
\hline
\end{tabular}




\subsection{Substrate Water Characteristic and Saturated Hydraulic Conductivity}

The continuous parametric WC models of van Genuchten (VG) [57] and Durner [58] were fitted to the measured matric potential and volumetric water content pairs (Figure 4). For calculation of integral water storage $\left(W_{I}\right)$ and integral energy $\left(E_{I}\right)$ the threshold matric potential at the wet-end $\left(h_{i}\right)$ of the $W C$ was set at $-2 \mathrm{~cm} \mathrm{H}_{2} \mathrm{O}$ below the substrate's air-entry potential (i.e., the potential at which the largest pore in the system starts draining and water is displaced by air-the transition from fully water-saturated to partially saturated) and the potential at the dry-end $\left(h_{f}\right)$ at $-440 \mathrm{~cm} \mathrm{H}_{2} \mathrm{O}$. The latter was adapted from [66] for spring tomatoes, which is the major crop of our greenhouse trials (Figure 4). It should be noted that while the matric potential has a negative subatmospheric pressure (lower potential means larger negative number- $-440 \mathrm{~cm}$ is lower than $-2 \mathrm{~cm}$ ), out of convenience it is commonly plotted on a positive scale with a minus sign in front of the units. It is also common to use units of lengths of $\mathrm{H}_{2} \mathrm{O}$ column (e.g., $\mathrm{m}$ ) for the matric potential, which can be converted to pressure units (e.g., $\mathrm{kPa})$ via multiplication with the density of water $\left(\mathrm{kg} \mathrm{m}^{-3}\right)$ and the acceleration due to gravity $\left(\mathrm{m} \mathrm{s}^{-1}\right)$. More details are provided in [12,15].

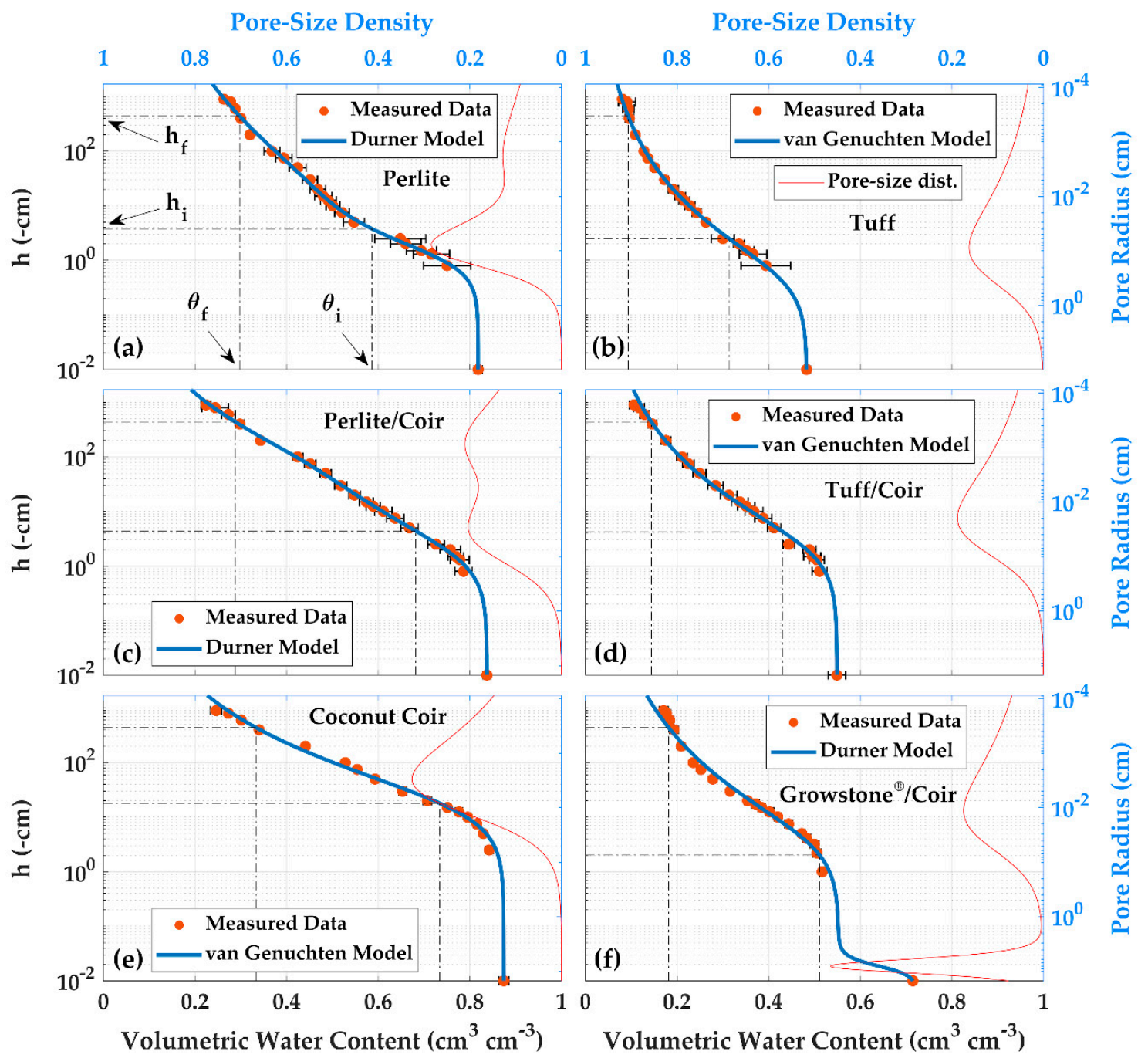

Figure 4. Measured WC data displayed with the fitted unimodal van Genuchten (Equation (6)) or bimodal Durner (Equation (7)) WC models for: (a) perlite, (b) tuff, (c) perlite/coconut coir, (d) tuff/coconut coir, (e) coconut coir, and (f) Growstone ${ }^{\circledR} /$ coconut coir. The error bars represent the standard deviation of the measured volumetric water contents. The wet- and dry-end matric potential thresholds, $h_{i}$ and $h_{f}$, and their corresponding water contents, $\theta_{i}$ and $\theta_{f}$, are marked with dash-dotted lines. The pore size distributions associated with the $W C$ curves are plotted on the right side. 
The hydraulic substrate properties consisting of the $W C$ model parameters and the saturated hydraulic conductivity $\left(K_{\text {sat }}\right)$ are listed in Table 3.

Table 3. Substrate WC parameters and measured $K_{\text {sat }}$ (for parameter definitions see Equations (6) and (7) in Section 2.3).

\begin{tabular}{|c|c|c|c|c|c|c|c|c|c|}
\hline Substrate & $\begin{array}{c}\theta_{r} \\
\left(\mathrm{~cm}^{3} \mathrm{~cm}^{-3}\right)\end{array}$ & $\begin{array}{c}\theta_{s} \\
\left(\mathrm{~cm}^{3} \mathrm{~cm}^{-3}\right)\end{array}$ & $\begin{array}{c}\alpha_{1} \\
\left(\mathrm{~cm}^{-1}\right)\end{array}$ & $n_{1}$ & $\begin{array}{c}\alpha_{2} \\
\left(\mathrm{~cm}^{-1}\right)\end{array}$ & $n_{2}$ & $w$ & $\begin{array}{c}K_{\text {sat }} \\
\left(\mathrm{cm} \mathrm{h}^{-1}\right)\end{array}$ & $\begin{array}{c}S E^{*} \\
\left(\mathrm{~cm} \mathrm{~h}^{-1}\right)\end{array}$ \\
\hline Perlite & 0.001 & 0.818 & 0.822 & 1.820 & 0.032 & 1.164 & 0.558 & 305.1 & 16.7 \\
\hline Tuff & 0.014 & 0.483 & 6.970 & 1.249 & - & - & - & 304.2 & 12.1 \\
\hline Coconut Coir & 0.010 & 0.874 & 0.062 & 1.296 & - & - & - & 56.2 & 5.1 \\
\hline Perlite/Coir & 0.005 & 0.837 & 0.599 & 1.331 & 0.011 & 1.318 & 0.416 & 165.1 & 8.4 \\
\hline Tuff/Coir & 0.014 & 0.549 & 0.458 & 1.267 & - & - & - & 110.7 & 11.6 \\
\hline Growstone ${ }^{\circledR} /$ Coir & 0.004 & 0.722 & 56.290 & 5.146 & 0.295 & 1.232 & 0.765 & 172.4 & 9.9 \\
\hline
\end{tabular}

* Standard error of $K_{\text {sat }}$ measurements.

The integral water storage and energy values calculated for each substrate are displayed in Table 4 together with their wet- and dry-end threshold water contents and $R$ values (Equation (10)).

Table 4. Integral water storage and energy values and associated threshold water contents (for parameter definitions see Equations (8) to (10) in Section 2.3).

\begin{tabular}{|c|c|c|c|c|c|}
\hline Substrate & $\begin{array}{c}\theta_{i} \\
\left(\mathrm{~cm}^{3} \mathrm{~cm}^{-3}\right)\end{array}$ & $\begin{array}{c}\theta_{f} \\
\left(\mathrm{~cm}^{3} \mathrm{~cm}^{-3}\right)\end{array}$ & $\begin{array}{c}W_{I} \\
\left(\mathrm{~cm}^{3} \mathrm{~cm}^{-3}\right)\end{array}$ & $E_{I}(\mathrm{~cm})$ & $\begin{array}{c}R \\
\left(\mathrm{~cm}^{3} \mathrm{~cm}^{-3} \mathrm{~cm}^{-1}\right) \times 10^{-3}\end{array}$ \\
\hline Perlite & 0.586 & 0.298 & 0.348 & 80.03 & 4.35 \\
\hline Tuff & 0.314 & 0.093 & 0.120 & 54.69 & 2.19 \\
\hline Coconut Coir & 0.734 & 0.333 & 0.431 & 120.65 & 3.57 \\
\hline Perlite/Coir & 0.681 & 0.288 & 0.372 & 96.94 & 3.83 \\
\hline Tuff/Coir & 0.431 & 0.144 & 0.187 & 69.02 & 2.71 \\
\hline Growstone ${ }^{\circledR} /$ Coir & 0.511 & 0.182 & 0.231 & 67.78 & 3.41 \\
\hline
\end{tabular}

Because of its aggregated structure, perlite exhibits a bimodal pore size distribution (Figure 4a) with distinct contributions of inter- and intra-aggregate pores [67]. The bimodal pore structure and WC that was well approximated with the Durner model (Figure 4a) is consistent with observations by [68], who applied mercury intrusion porosimetry to measure the pore size distribution of uncrushed expanded perlite. It should be noted that a distinct bimodal pore structure of perlite was not reported in [69-71]. The saturated hydraulic conductivity of perlite that was slightly above that of tuff (Table 3) falls within the range provided in [70]. Based on the $W_{I}, E_{I}$, and $R$ values listed in Table 4 , it is obvious that the plant water availability (accessibility) of perlite is the highest of all investigated substrates. In other words, perlite yields the highest water amount between the respective threshold water contents $\left(\theta_{i}\right.$ and $\left.\theta_{f}\right)$ per unit energy exerted by plant roots.

In contrast to perlite, tuff provides the lowest water yield of the investigated substrates between $\theta_{i}$ and $\theta_{f}$ (Table 4). This in conjunction with its high $K_{\text {sat }}$ (Table 3) indicates rapid drainage of the fertigation solution from the substrate, which provides valuable insights for irrigation and fertigation management to avoid problems with water and nutrient deficiencies. For example, an increase in irrigation frequency to keep the matric potential above $-200 \mathrm{~cm}$ would double the plant water yield for the same applied energy. Wallach et al. [17] measured hydraulic characteristics of two red tuff varieties and reported $K_{\text {sat }}$ values of 130 and $439 \mathrm{~cm} \mathrm{~h}^{-1}$ and associated dry bulk densities of 1.227 and $1.091 \mathrm{~g} \mathrm{~cm}^{-3}$, respectively. They also evaluated the capability of the Mualem hydraulic conductivity model [72] to estimate unsaturated hydraulic conductivity from van Genuchten WC model parameters and found good agreement with data measured for tuff.

Coconut coir exhibits the lowest $K_{\text {sat }}$ of the investigated substrates-about one-sixth of that of perlite and tuff (Table 3). Because of differences in industrial source and pretreatment of coconut coir, considerable variations in physicochemical and hydraulic properties can be expected [51]. The measured 
$K_{\text {sat }}$ of $56.2 \mathrm{~cm} \mathrm{~h}^{-1}$ is about half of that measured by [73], who compacted the samples to a similar bulk density as used in this study. The $K_{\text {sat }}$ value reported in [74] is more than one order of magnitude higher than our measurements, but due to the lack of information about the associated bulk density a direct comparison is not feasible. Their extremely high $K_{\text {sat }}$ is most likely due to a much lower bulk density of the coconut coir in the narrow glass columns that were used in their experiments, which is also evident from the van Genuchten WC model $\alpha$-parameter reported in [74]. In general, horticultural coconut coir does not contain a significant number of large pores. This is why it is commonly mixed with aggregated mineral substrates to enhance aeration properties [53]. In terms of plant water availability (i.e., $R$-value), pure coconut coir yields more water per unit of energy exerted by plant roots within the $\theta_{i}-\theta_{f}$ range than the tuff/coconut coir and Growstone ${ }^{\circledR} /$ coconut coir mixtures (Table 4 ).

The perlite/coconut coir and tuff/coconut coir mixtures exhibit hydraulic properties that fall in between the properties of their constituents (Figure 4c,d; Tables 3 and 4). This includes their air-entry potentials, which enhances aeration relative to sole coconut coir. The addition of coconut coir to perlite and tuff also lowers the $K_{\text {sat }}$ of the mixtures, slowing down drainage and increasing the water yield (availability) within the $\theta_{i}-\theta_{f}$ range. For example, the $70 / 30$ vol.- $\%$ tuff/coconut coir mixture has a $19 \%$ higher $R$ value than the sole tuff substrate (Table 4 ). Such information may be utilized to optimize (engineer) substrate mixtures via varying mixing ratios to achieve optimum plant specific growth environments in terms of total porosity, air-filled porosity, available water, aeration, and bulk density $[10,14,75]$ as well as to provide guidance for selection of container geometry and irrigation and fertigation management [76-78].

The Growstone ${ }^{\circledR} /$ coconut coir mixture has the highest (i.e., least negative) air-entry potential of the investigated substrates (Figure 4), which is also evident from the high $\alpha_{1}$ Durner WC model parameter (Table 3). From Figure 4, it is evident that a $-1 \mathrm{~cm}$ change in matric potential will cause an almost instantaneous drainage of water from about $25 \%$ of the entire pore space. As shown in [14], where both the WC and aeration properties of four soilless substrates were measured, caution is required when assessing aeration properties of mixtures containing large aggregates as water blockage and pore discontinuities might occur.

\subsection{Phosphorus and Ammonium Adsorption}

The Langmuir adsorption isotherm parameters for both phosphorus and ammonium are summarized in Table 5. The maximum amount of phosphorus adsorbed onto perlite, coconut coir, and the perlite/coconut coir mixture of about $20 \mathrm{mg}$ per kilogram of solid is negligibly small. The low phosphorus absorptivity of perlite was previously reported by [63,79], who evaluated perlite as a potential filtration medium for urban runoff. Low phosphorus adsorption onto coconut coir was indicated in $[80,81]$. Tuff and the Growstone ${ }^{\circledR} /$ coconut coir mixture exhibited the highest phosphorus adsorption per unit substrate mass, about 15 and 12 times that of perlite and coconut coir (Table 5), respectively. It should be noted that while tuff and the Growstone ${ }^{\circledR} /$ coconut coir mixture show about the same capacity for phosphorus adsorption per unit substrate mass, the adsorption onto tuff within the same container volume will be more than six times higher than that onto the Growstone ${ }^{\circledR} /$ coconut $^{-}$ coir mixture because of the significantly higher dry bulk density of tuff (Table 1).

Figure 5 depicts the measured equilibrium concentrations for both ammonium and phosphorus together with the fitted Langmuir isotherms. The low coefficients of determination $\left(R^{2}\right)$ for perlite, coconut coir, and Growstone ${ }^{\circledR} /$ coconut coir are attributable to low adsorption values (perlite and coconut coir) and the uncertainty inherent to the measurement procedure. 
Table 5. Langmuir adsorption isotherm parameters for phosphorus and ammonium.

\begin{tabular}{|c|c|c|c|c|}
\hline \multirow[b]{2}{*}{ Substrate } & \multicolumn{2}{|c|}{ Phosphorus } & \multicolumn{2}{|c|}{ Ammonium } \\
\hline & $\begin{array}{c}S_{\max } \\
\left(\mathrm{mg} \mathrm{kg}^{-1}\right)\end{array}$ & $\begin{array}{c}k \\
\left(1 \mathrm{mg}^{-1}\right. \\
\left.\mathrm{KH}_{2} \mathrm{PO}_{4}-\mathrm{P}\right)\end{array}$ & $\begin{array}{c}S_{\max } \\
\left(\mathrm{mg} \mathrm{kg}^{-1}\right)\end{array}$ & $\left(\mathrm{mg}^{-1} \mathrm{NH}_{4}-\mathrm{N}\right)$ \\
\hline Perlite & 18.0 & 0.984 & 43.6 & 3.376 \\
\hline Tuff & 270.6 & 0.066 & 432.8 & 0.135 \\
\hline Coconut Coir & 23.0 & 0.548 & 1419.5 & 0.036 \\
\hline Perlite/Coir & 24.2 & 0.327 & 809.0 & 0.056 \\
\hline Tuff/Coir & 241.8 & 0.102 & 517.3 & 0.083 \\
\hline Growstone ${ }^{\circledR} /$ Coir & 265.5 & 0.036 & 473.6 & 0.054 \\
\hline
\end{tabular}
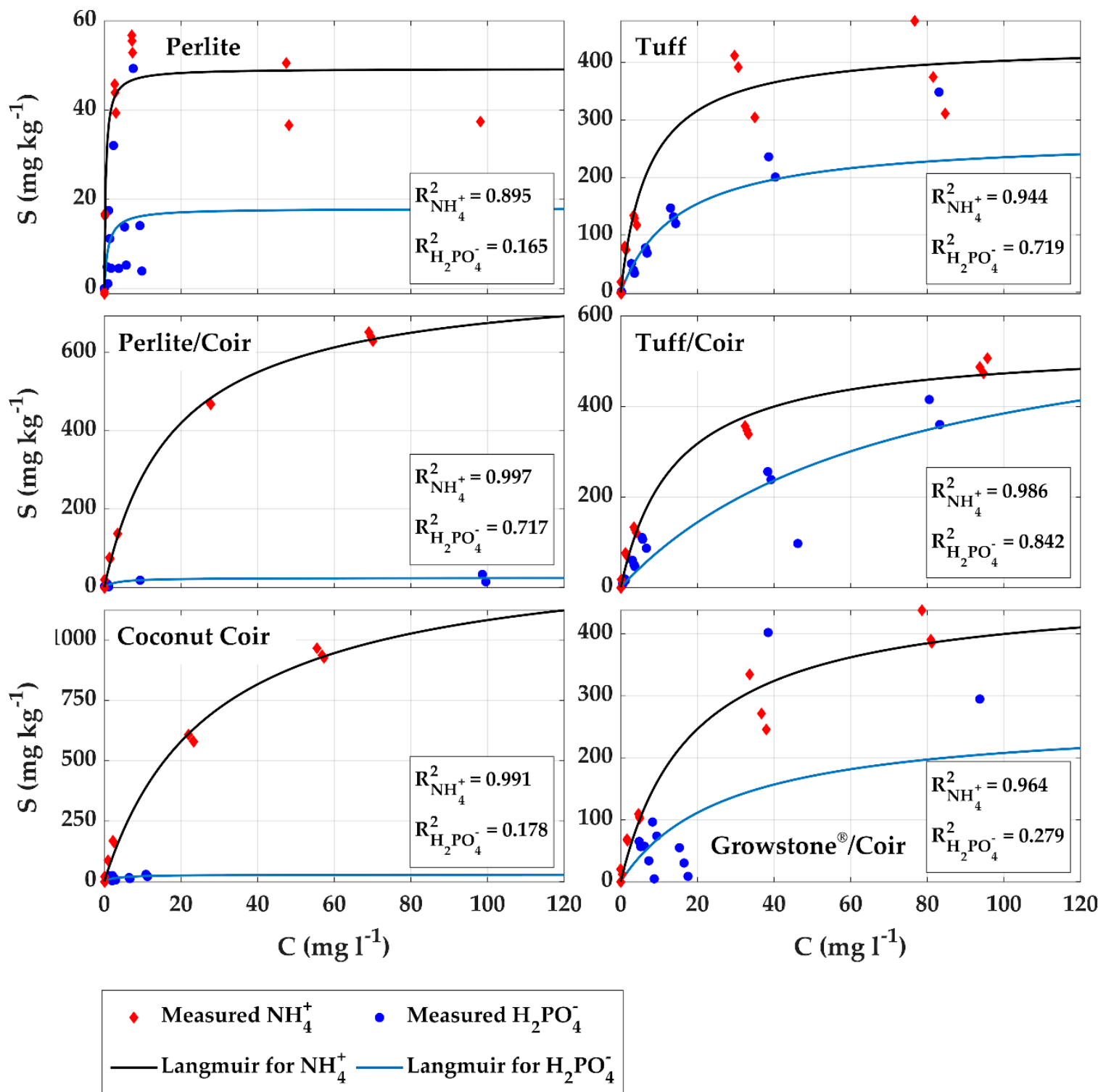

Figure 5. Measured $\mathrm{NH}_{4}{ }^{+}$and $\mathrm{H}_{2} \mathrm{PO}_{4}{ }^{-}$equilibrium concentrations displayed with the fitted Langmuir adsorption isotherms and the associated coefficients of determination.

The $k$ coefficient in the Langmuir equation represents the affinity of the adsorbed species to the adsorbent (i.e., the higher $k$, the stronger the affinity). When the affinity is stronger, maximal adsorption is attained at lower adsorbate concentrations and there is a sharp increase in the adsorbed amount at 
low concentrations. The $k$ values in Table 5 indicate that the order of affinities of phosphorus to the substrates is perlite $>$ coconut coir $>$ perlite/coconut coir mixture $>$ tuff/coconut coir mixture $>$ tuff $>$ Growstone ${ }^{\circledR} /$ coconut coir mixture. Despite the high affinity of phosphorus to perlite, the importance of phosphorus adsorption is small due to the combination of low $S_{\max }$ and low bulk density. It was expected that the $k$ values of mixtures of two components fall between the values of the pure components. However, note that the $k$ of the perlite/coconut coir mixture is smaller than that of coconut coir, most likely due to chemical interactions between the coconut coir and perlite surfaces. The $k$ value of the tuff/coconut coir mixture is much closer to that of tuff, which may be attributed to the much higher bulk density of tuff.

Because of its high cation exchange capacity (CEC) [51,82], which is the most important factor for ammonium adsorption [83], the maximum amount $\left(S_{\max }\right)$ of ammonium was adsorbed onto coconut coir. This translates to the mixtures containing coconut coir (Table 5). Perlite exhibited the lowest $S_{\max }$ value of the investigated substrates, which together with its low bulk density indicates that ammonium adsorption onto perlite is rather negligible. It should be noted that because the substrates were mixed on a volume basis, the dry mass ratio parameter $(\vartheta)$ in Equation (1) is crucial for estimation of adsorption properties of the substrate mixtures. For example, the 30 vol.- $\%$ coconut coir contained in the tuff/coconut coir mixture does not significantly increase ammonium adsorption. In contrast, the 50 vol.- $\%$ coconut coir contained in the perlite/coconut coir mixture significantly impacts ammonium adsorption due to an almost 30 times lower $\vartheta$ than that of the tuff/coconut coir mixture. The $k$ values in Table 5 indicate that the order of affinities of ammonium to the substrates is perlite $>$ tuff $>$ tuff/coconut coir $>$ perlite/coconut coir $>$ coconut coir $>$ Growstone ${ }^{\circledR} /$ coconut coir. Similar to phosphorus, the importance of ammonium adsorption to perlite is small due to the combination of low $S_{\max }$ and low bulk density. As expected, the $k$ values for ammonium in the two component mixtures fall in between the values of the pure components.

\section{Conclusions}

A thorough physicochemical and hydraulic characterization of six soilless substrates and substrate mixtures that were selected based on ongoing greenhouse trials was presented. The investigated substrates included perlite, volcanic tuff, coconut coir, a 50/50 vol.- $\%$ perlite/coconut coir mixture, a 70/30 vol.- $\%$ volcanic tuff/coconut coir mixture, and a 50/50 vol.- $\%$ foamed glass aggregate (i.e., Growstones ${ }^{\circledR}$ )/coconut coir mixture. After developing a precise sample preparation procedure to assure high repeatability, the substrate $W C, K_{\text {sat }}$, particle densities, average bulk densities, as well as phosphorus and ammonium adsorption isotherms were measured with state-of-the-art techniques. The WC measurements were used to parameterize the unimodal van Genuchten [57] and bimodal Durner [58] WC models to derive integral water and energy storage parameters to estimate the amount of water that can be extracted from a specific volumetric water content range per unit energy exerted by plant roots. From integral energy calculations, it is evident that plant water availability (accessibility) of perlite is the highest of all investigated substrates, followed by the perlite/coconut coir mixture. Perlite also exhibits favorable nutrient adsorption characteristics. Despite the high affinity of phosphorus to perlite the importance of $\mathrm{P}$ adsorption is small due to a low maximum adsorption capacity and the low bulk density of perlite. In addition, ammonium adsorption to perlite is rather negligible. The obtained soilless substrate parameters can not only be applied for optimization (engineering) of soilless substrates via mixing of organic and inorganic constituents at different ratios to meet specific plant physiological demands, but also used for the parameterization of three-dimensional numerical computer codes for simulation of water and nutrient dynamics in containerized growth modules to aid with their design and management as well as to provide scientifically sound data for the design of greenhouse trials to avoid costly trial and error experiments, which motivated this study and is part of our ongoing research. 
Author Contributions: Conceptualization, A.B.-T., M.R.G., and M.T.; methodology, M.R.G and M.T.; investigation, M.E. and M.R.G.; data analysis, M.E., M.R.G., and M.T.; writing-original draft preparation, M.E., M.R.G., and M.T.; writing - review and editing, A.B.-T., M.E., M.R.G., and M.T.; funding acquisition, A.B.-T. and M.T. All authors have read and agreed to the published version of the manuscript.

Funding: This research was funded by The United States-Israel Binational Agricultural Research and Development Fund (BARD), grant number US-4764-14 R, and by the United States Department of Agriculture (USDA) National Institute of Food and Agriculture (NIFA), Hatch/Multi-State project number ARZT-1370600-R21-189.

Conflicts of Interest: The authors declare no conflict of interest.

\section{References}

1. United Nations, Department of Economic and Social Affairs, Population Division. World Population Prospects 2019: Highlights (ST/ESA/SER.A/423); United Nations: New York, NY, USA, 2019.

2. Artuso, F.; Guijt, I. Global Megatrends-Mapping the Forces that Affect Us All; Oxfam GB: Oxford, UK, 2020; ISBN 978-1-78748-564-8.

3. Newman, E. Hungry, or Hungry for Change? Food Riots and Political Conflict, 2005-2015. Stud. Confl. Terror. 2020, 43, 300-324. [CrossRef]

4. Wheeler, T.; von Braun, J. Climate change impacts on global food security. Science 2013, 341, 508-513. [CrossRef] [PubMed]

5. Raviv, M.; Lieth, J.H.; Bar-Tal, A. Significance of Soilless Culture in Agriculture. In Soilless Culture: Theory and Practice, 2nd ed.; Raviv, M., Lieth, J.H., Bar-Tal, A., Eds.; Academic Press: London, UK, 2019; pp. 3-14.

6. Gruda, N.S. Increasing sustainability of growing media constituents and stand-alone substrates in soilless culture systems. Agronomy 2019, 9, 298. [CrossRef]

7. Savvas, D. Hydroponics: A modern technology supporting the application of integrated crop management in greenhouse. J. Food Agric. Environ. 2003, 1, 80-86.

8. Raviv, M. Can compost improve sustainability of plant production in growing media? In Proceedings of the International Symposium on Growing Media, Composting and Substrate Analysis-SusGro2015, Vienna, Austria, 7-11 September 2015; pp. 119-134.

9. Bar-Tal, A.; Saha, U.K.; Raviv, M.; Tuller, M. Inorganic and Synthetic Organic Components of Soilless Culture and Potting Mixtures. In Soilless Culture: Theory and Practice, 2nd ed.; Raviv, M., Lieth, J.H., Bar-Tal, A., Eds.; Academic Press: London, UK, 2019; pp. 259-301.

10. Yeager, T.; Gilliam, C.; Bilderback, T.E.; Fare, D.; Niemiera, A.; Tilt, K. Best Management Practices: Guide for Producing Container-Grown Plants; Southern Nursery Association: Acworth, GA, USA, 2000.

11. Caron, J.; Pepin, S.; Periard, Y. Physics of growing media in a green future. In Proceedings of the International Symposium on Growing Media and Soilless Cultivation, Leiden, Netherlands, 17-21 June 2013; pp. 309-317.

12. Tuller, M.; Or, D. Water Retention and Characteristic Curve. In Encyclopedia of Soils in the Environment; Hillel, D., Ed.; Elsevier: London, UK, 2005; pp. 278-289.

13. Wallach, R.; Da Silva, F.F.; Chen, Y. Hydraulic characteristics of tuff (scoria) used as a container medium. J. Am. Soc. Hortic. Sci. 1992, 117, 415-421. [CrossRef]

14. Deepagoda, T.K.K.C.; Lopez, J.C.C.; Møldrup, P.; de Jonge, L.W.; Tuller, M. Integral parameters for characterizing water, energy, and aeration properties of soilless plant growth media. J. Hydrol. 2013, 502, 120-127. [CrossRef]

15. Or, D.; Tuller, M.; Or, D.; Wraith, J.M. Water Potential. In Encyclopedia of Soils in the Environment; Hillel, D., Ed.; Elsevier: London, UK, 2005; pp. 270-277.

16. Lieth, J.H.; Oki, L.R. Irrigation in soilless production. In Soilless Culture: Theory and Practice, 1st ed.; Raviv, M., Lieth, J.H., Eds.; Elsevier Science: London, UK, 2007; pp. 117-156.

17. Veihmeyer, F.J.; Hendrickson, A.H. Soil moisture in relation to plant growth. Annu. Rev. Plant Physiol. 1950, 1, 285-304. [CrossRef]

18. De Boodt, M.; Verdonck, O. The physical properties of the substrates in horticulture. In Proceedings of the III Symposium on Peat in Horticulture, Dublin, Ireland, 28 June-3 July 1971; pp. 37-44.

19. White, J.W.; Mastalerz, J.W. Soil moisture as related to container capacity. In Proceedings of the American Society for Horticultural Science; Am. Soc. Horticultural Science: Alexandria, VA, USA, 1966; Volume 89, p. 758.

20. Bilderback, T.E.; Fonteno, W.C. Effects of container geometry and media physical properties on air and water volumes in containers. J. Environ. Hortic. 1987, 5, 180-182. [CrossRef] 
21. Fonteno, W.C. An approach to modeling air and water status of horticultural substrates. In Proceedings of the Symposium on Substrates in Horticulture other than Soils in Situ, Dublin, Ireland, 12-16 September 1988; pp. 67-74.

22. Letey, J. Relationship between soil physical properties and crop production. In Advances in Soil Science; Springer: New York, NY, USA, 1985; pp. 277-294.

23. Da Silva, A.P.; Kay, B.D.; Perfect, E. Characterization of the least limiting water range of soils. Soil Sci. Soc. Am. J. 1994, 58, 1775-1781. [CrossRef]

24. Groenevelt, P.H.; Grant, C.D.; Semetsa, S. A new procedure to determine soil water availability. Soil Res. 2001, 39, 577-598. [CrossRef]

25. Minasny, B.; McBratney, A.B. Integral energy as a measure of soil-water availability. Plant Soil 2003, 249, $253-262$. [CrossRef]

26. Da Silva, F.F.; Wallach, R.; Chen, Y. Hydraulic properties of sphagnum peat moss and tuff (scoria) and their potential effects on water availability. In Optimization of Plant Nutrition; Springer: Berlin/Heidelberg, Germany, 1993; pp. 569-576.

27. Raviv, M.; Wallach, R.; Silber, A.; Medina, S.; Krasnovsky, A. The effect of hydraulic characteristics of volcanic materials on yield of roses grown in soilless culture. J. Am. Soc. Hortic. Sci. 1999, 124, 205-209. [CrossRef]

28. Loneragan, J.F. Plant nutrition in the 20th and perspectives for the 21st century. In Plant Nutrition for Sustainable Food Production and Environment; Springer: Berlin/Heidelberg, Germany, 1997; pp. 3-14.

29. Savvas, D. Nutritional management of vegetables and ornamental plants in hydroponics. Crop Manag. Postharvest Handl. Hortic. Prod. 2001, 1, 37-87.

30. Silber, A.; Bar-Tal, A. Nutrition of Substrate-Grown Plants. In Soilless Culture: Theory and Practice, 2nd ed.; Raviv, M., Lieth, J.H., Bar-Tal, A., Eds.; Academic Press: London, UK, 2019; pp. 197-257.

31. Silber, A. Chemical characteristics of soilless media. In Soilless Culture: Theory and Practice, 2nd ed.; Raviv, M., Lieth, J.H., Bar-Tal, A., Eds.; Academic Press: London, UK, 2019; pp. 113-148.

32. Willard, L.L. Chemical Equilibria in Soils; John Wiley \& Sons: Chichester, UK, 1979.

33. Silber, A.; Xu, G.; Levkovitch, I.; Soriano, S.; Bilu, A.; Wallach, R. High fertigation frequency: The effects on uptake of nutrients, water and plant growth. Plant Soil 2003, 253, 467-477. [CrossRef]

34. Silber, A.; Bruner, M.; Kenig, E.; Reshef, G.; Zohar, H.; Posalski, I.; Yehezkel, H.; Shmuel, D.; Cohen, S.; Dinar, M. High fertigation frequency and phosphorus level: Effects on summer-grown bell pepper growth and blossom-end rot incidence. Plant Soil 2005, 270, 135-146. [CrossRef]

35. Xu, S.; Lam, J. Positive real control for uncertain singular time-delay systems via output feedback controllers. Eur. J. Control. 2004, 10, 293-302. [CrossRef]

36. Gerendás, J.; Zhu, Z.; Bendixen, R.; Ratcliffe, R.G.; Sattelmacher, B. Physiological and biochemical processes related to ammonium toxicity in higher plants. Z. Pflanz. Bodenkd. 1997, 160, 239-251.

37. Savvas, D.; Karagianni, V.; Kotsiras, A.; Demopoulos, V.; Karkamisi, I.; Pakou, P. Interactions between ammonium and $\mathrm{pH}$ of the nutrient solution supplied to gerbera (Gerbera jamesonii) grown in pumice. Plant Soil 2003, 254, 393-402. [CrossRef]

38. Bar-Tal, A.; Aloni, B.; Karni, L.; Rosenberg, R. Nitrogen nutrition of greenhouse pepper. II. Effects of nitrogen concentration and $\mathrm{NO}_{3}: \mathrm{NH}_{4}$ ratio on growth, transpiration, and nutrient uptake. HortScience 2001, 36, 1252-1259. [CrossRef]

39. Claussen, W.; Lenz, F. Effect of ammonium or nitrate nutrition on net photosynthesis, growth, and activity of the enzymes nitrate reductase and glutamine synthetase in blueberry, raspberry and strawberry. Plant Soil 1999, 208, 95-102. [CrossRef]

40. Magalhaes, J.R.; Wilcox, G.E. Growth, free amino acids, and mineral composition of tomato plants in relation to nitrogen form and growing media. J. Am. Soc. Hortic. Sci. 1984, 109, 406-411.

41. Ganmore-Neumann, R.; Kafkafi, U. Root Temperature and Percentage NO3-/NH4 Effect on Tomato Plant Development I. Morphology and Growth. Agron. J. 1980, 72, 758-761. [CrossRef]

42. Alkan, M.; Do, M. Surface Titrations of Perlite Suspensions. J. Colloid Interface Sci. 1998, 207, 90-96. [CrossRef] [PubMed]

43. Kaufhold, S.; Reese, A.; Schwiebacher, W.; Dohrmann, R.; Grathoff, G.H.; Warr, L.N.; Halisch, M.; Muller, C.; Schwarz-Schampera, U.; Ufer, K. Porosity and distribution of water in perlite from the island of Milos, Greece. Springerplus 2014, 3, 598. [CrossRef] [PubMed]

44. Noland, D.A.; Spomer, L.A.; Williams, D.J. Evaluation of pumice as a perlite substitute for container soil physical amendment. Commun. Soil Sci. Plant Anal. 1992, 23, 1533-1547. [CrossRef] 
45. Kingston, P.H.; Scagel, C.F.; Bryla, D.R.; Strik, B.C. Influence of Perlite in Peat-and Coir-based Media on Vegetative Growth and Mineral Nutrition of Highbush Blueberry. HortScience 2020, 55, 658-663. [CrossRef]

46. Muñoz, C.; Soto, R.; Valenzuela, J. Effect of chemical and physical potting media characteristics on growth of container-grown rabbiteye blueberries. In Proceedings of the V International Symposium on Vaccinium Culture, Melbourne, Australia, 14-16 January 1993; pp. 162-172.

47. Bugbee, G.J.; Frink, C.R. Aeration of potting media and plant growth. Soil Sci. 1986, 141, 438-441. [CrossRef]

48. Silber, A.; Bar-Yosef, B.; Singer, A.; Chen, Y. Mineralogical and chemical composition of three tuffs from northern Israel. Geoderma 1994, 63, 123-144. [CrossRef]

49. Silber, A.; Bar-Yosef, B.; Chen, Y. pH-dependent kinetics of tuff dissolution. Geoderma 1999, 93, $125-140$. [CrossRef]

50. Silber, A.; Raviv, M. Effects on chemical surface properties of tuff by growing rose plants. Plant Soil 1996, 186, 353-360. [CrossRef]

51. Evans, M.R.; Konduru, S.; Stamps, R.H. Source variation in physical and chemical properties of coconut coir dust. HortScience 1996, 31, 965-967. [CrossRef]

52. Abad, M.; Fornes, F.; Carrión, C.; Noguera, V.; Noguera, P.; Maquieira, Á.; Puchades, R. Physical properties of various coconut coir dusts compared to peat. HortScience 2005, 40, 2138-2144. [CrossRef]

53. Londra, P.A.; Paraskevopoulou, A.T.; Psychoyou, M. Evaluation of water-Air balance of various substrates on Begonia growth. HortScience 2012, 47, 1153-1158. [CrossRef]

54. Mak, A.T.Y.; Yeh, D.M. Nitrogen nutrition of Spathiphyllum 'Sensation' grown in Sphagnum peat-and coir-based media with two irrigation methods. HortScience 2001, 36, 645-649. [CrossRef]

55. Meerow, A.W. The Potential of Coir (Coconut Mesocarp Pith) as a Peat Substitute in Container Media. HortScience 1994, 29, 452. [CrossRef]

56. Evans, M.R. Physical properties of and plant growth in peat-based root substrates containing glass-based aggregate, perlite, and parboiled fresh rice hulls. HortTechnology 2011, 21, 30-34. [CrossRef]

57. Van Genuchten, M.T. A closed-form equation for predicting the hydraulic conductivity of unsaturated soils. Soil Sci. Soc. Am. J. 1980, 44, 892-898. [CrossRef]

58. Durner, W. Hydraulic conductivity estimation for soils with heterogeneous pore structure. Water Resour. Res. 1994, 30, 211-223. [CrossRef]

59. Reynolds, W.D.; Elrick, D.E.; Youngs, E.G.; Booltink, H.W.G.; Bouma, J. Saturated and Field-Saturated Water Flow Parameters: Laboratory Methods. In Methods of Soil Analysis: Part 4—Physical Methods, 5.4; Dane, J.H., Topp, G.C., Eds.; Soil Science Society of America, Inc.: Madison, WI, USA, 2002; pp. 802-816.

60. Flint, A.L.; Flint, L.E. Particle Density. In Methods of Soil Analysis: Part 4-Physical Methods, 5.4; Dane, J.H., Topp, G.C., Eds.; Soil Science Society of America, Inc.: Madison, WI, USA, 2002; pp. 229-240.

61. Kovar, J.L.; Pierzynski, G.M. Methods of phosphorus analysis for soils, sediments, residuals, and waters, 2nd edition. South. Coop. Ser. Bull. 2009, 408, 33-37.

62. Kempers, A.J.; Zweers, A. Ammonium determination in soil extracts by the salicylate method. Commun. Soil Sci. Plant Anal. 1986, 17, 715-723. [CrossRef]

63. Ma, J.; James Lenhart, P.E.; WRE, D. Phosphorus Removal in Urban Runoff Using Adsorptive Filtration Media. In Proceedings of the StormCon, Anaheim, CA, USA, 16-20 August 2009; pp. 16-20.

64. Ghazvini, R.F.; Payvast, G.; Azarian, H. Effect of clinoptiloliticzeolite and perlite mixtures on the yield and quality of strawberry in soil-less culture. Int. J. Agric. Biol. 2007, 9, 885-888.

65. Demirboğa, R.; Gül, R. The effects of expanded perlite aggregate, silica fume and fly ash on the thermal conductivity of lightweight concrete. Cem. Concr. Res. 2003, 33, 723-727. [CrossRef]

66. Thompson, R.B.; Gallardo, M.; Valdez, L.C.; Fernández, M.D. Using plant water status to define threshold values for irrigation management of vegetable crops using soil moisture sensors. Agric. Water Manag. 2007, 88, 147-158. [CrossRef]

67. Smettem, K.R.J.; Kirkby, C. Measuring the hydraulic properties of a stable aggregated soil. J. Hydrol. 1990, 117, 1-13. [CrossRef]

68. Jamei, M.; Guiras, H.; Chtourou, Y.; Kallel, A.; Romero, E.; Georgopoulos, I. Water retention properties of perlite as a material with crushable soft particles. Eng. Geol. 2011, 122, 261-2718. [CrossRef]

69. Londra, P.A. Simultaneous Determination of Water Retention Curve and Unsaturated Hydraulic Conductivity of Substrates Using a Steady-state Laboratory Method. HortScience 2010, 45, 1106-1112. [CrossRef] 
70. Giuffrida, F.; Consoli, S. Reusing perlite substrates in soilless cultivation: Analysis of particle size, hydraulic properties, and solarization effects. J. Irrig. Drain. Eng. 2016, 142, 4015047. [CrossRef]

71. Al Naddaf, O.; Livieratos, I.; Stamatakis, A.; Tsirogiannis, I.; Gizas, G.; Savvas, D. Hydraulic characteristics of composted pig manure, perlite, and mixtures of them, and their impact on cucumber grown on bags. Sci. Hortic. 2011, 129, 135-141. [CrossRef]

72. Mualem, Y. A new model for predicting the hydraulic conductivity of unsaturated porous media. Water Resour. Res. 1976, 12, 513-522. [CrossRef]

73. Quintero, M.F.; González, C.A.; Florez-Roncancio, V.J. Physical and hydraulic properties of four substrates used in the cut-flower industry in Colombia. In Proceedings of the III International Symposium on Models for Plant Growth, Environmental Control and Farm Management in Protected Cultivation, Wageningen, Netherlands, 29 October-2 November 2006; pp. 499-506.

74. Raviv, M.; Lieth, J.H.; Burger, D.W.; Wallach, R. Optimization of Transpiration and Potential Growth Rates of Kardinal Rose with Respect to Root-zone Physical Properties. J. Am. Soc. Hortic. Sci. 2001, 126, 638-643. [CrossRef]

75. Chamindu Deepagoda, T.K.K.; Moldrup, P.; Tuller, M.; Pedersen, M.; Lopez, C.; Choc, J.; Wollesen de Jonge, L.; Kawamoto, K.; Komatsu, T. Gas diffusivity-based design and characterization of greenhouse growth substrates. Vadose Zone J. 2013, 12, 1-13. [CrossRef]

76. Riga, P.; Álava, S.; Usón, A.; Blanco, F.; Garbisu, C.; Aizpurua, A.; Tejero, T.; Larrea, A. Evaluation of recycled rockwool as a component of peat-based mixtures for geranium (Pelargonium peltatum L.) production. J. Hortic. Sci. Biotechnol. 2003, 78, 213-218. [CrossRef]

77. Caron, J.; Elrick, D.E.; Beeson, R.; Boudreau, J. Defining critical capillary rise properties for growing media in nurseries. Soil Sci. Soc. Am. J. 2005, 69, 794-806. [CrossRef]

78. Jones, S.B.; Or, D. Design of porous media for optimal gas and liquid fluxes to plant roots. Soil Sci. Soc. Am. J. 1998, 62, 563-573. [CrossRef]

79. Ma, J.; Lenhart, J.H.; Tracy, K. Orthophosphate adsorption equilibrium and breakthrough on filtration media for storm-water runoff treatment. J. Irrig. Drain. Eng. 2011, 137, 244-250. [CrossRef]

80. Kumar, P.; Sudha, S.; Chand, S.; Srivastava, V.C. Phosphate removal from aqueous solution using coir-pith activated carbon. Sep. Sci. Technol. 2010, 45, 1463-1470. [CrossRef]

81. Namasivayam, C.; Sangeetha, D. Equilibrium and kinetic studies of adsorption of phosphate onto $\mathrm{ZnCl}_{2}$ activated coir pith carbon. J. Colloid Interface Sci. 2004, 280, 359-365. [CrossRef]

82. Kumarasinghe, H.; Subasinghe, S.; Ransimala, D. Effect of coco peat particle size for the optimum growth of nursery plant of greenhouse vegetables. Trop. Agric. Res. Ext. 2016, 18, 51-57. [CrossRef]

83. Gai, X.; Wang, H.; Liu, J.; Zhai, L.; Liu, S.; Ren, T.; Liu, H. Effects of feedstock and pyrolysis temperature on biochar adsorption of ammonium and nitrate. PLOS ONE 2014, 9, e113888. [CrossRef] 